\title{
Modeling temporal variations of Gracilaria Greville and Hypnea J.V. Lamouroux (Rhodophyta) assemblages on a midlittoral reef platform at Piedade Beach, Pernambuco State, Brazil
}

\author{
MARIANA ALVES DE GUIMARAENS ${ }^{1,4}$, SILVIO JOSÉ DE MACEDO², \\ MARIA DE FÁTIMA DE OLIVEIRA-CARVALHO ${ }^{3}$, DOUGLAS CORREIA BURGOS ${ }^{3}$ and \\ SONIA MARIA BARRETO PEREIRA ${ }^{3}$
}

(received: February 20, 2012; accepted: November 19, 2012)

\begin{abstract}
Modeling temporal variations of Gracilaria Greville and Hypnea J.V. Lamouroux (Rhodophyta) assemblages on a midlittoral reef platform at Piedade Beach, Pernambuco State, Brazil). The diversity of algal banks composed of species out the genera Gracilaria Greville and Hypnea J.V. Lamouroux have been impacted by commercial exploitation and coastal eutrophication. The present study sought to construct dynamic models based on algal physiology to simulate seasonal variations in the biomasses of Gracilaria and Hypnea an intertidal reef at Piedade Beach in Jaboatão dos Guararapes, Pernambuco State, Brazil. Five $20 \times 20 \mathrm{~cm}$ plots in a reef pool on a midlittoral reef platform were randomly sampled during April, June, August, October, and December/2009 and in January and March/2010. Water temperature, $\mathrm{pH}$, irradiance, oxygen and salinity levels as well as the concentrations of ammonia, nitrate and phosphate were measured at the sampling site. Forcing functions were employed in the model to represent abiotic factors, and algal decay was simulated with a dispersal function. Algal growth was modeled using a logistic function and was found to be sensitive to temperature and salinity. Maximum absorption rates of ammonia and phosphate were higher in Hypnea than in Gracilaria, indicating that the former takes up nutrients more efficiently at higher concentrations. Gracilaria biomass peaked at approximately $120 \mathrm{~g}$ (dry weight $\mathrm{m}^{-2}$ ) in March/2010 and was significantly lower in August/2009; Hypnea biomasses, on the other hand, did not show any significant variations among the different months, indicating that resource competition may influence the productivity of these algae.
\end{abstract}

Keywords - algal biomass, eutrophication, sandstone reefs, trophic models

\section{INTRODUCTION}

The red algae Gracilaria Greville and Hypnea J.V. Lamouroux are widely distributed along the Brazilian coast, but their stocks have been reduced in some coastal areas due to industrial harvesting for agar and carrageenan production respectively (Oliveira Filho 1998, Miranda 2010). Among the dominant algae at the sampling site on Piedade Reef were Gracilaria caudata J. Agardh and Hypnea musciformis (Wulfen) J.V. Lamouroux, which could be found directly attached to the reef substrate or living as epiphytes (Guimaraens et al. 1996). Due to the economic importance of Hypnea musciformis and certain species of the Gracilaria genus, several laboratory and field cultivation studies have been undertaken to examine the effects of abiotic factors (salinity, nutrient

1. Universidade de Pernambuco, Instituto de Ciências Biológicas, Departamento de Biologia, Rua Arnóbio Marques, 310, 50100-130 Recife, PE, Brazil.

2. Universidade Federal de Pernambuco, Departamento de Oceanografia, 50610-910 Recife, PE, Brazil.

3. Universidade Federal Rural de Pernambuco, Departamento de Biologia, Programa de Pós-Graduação em Botânica, Av. D. Manoel de Medeiros, s/n., 52171-900 Recife, PE, Brazil.

4. Corresponding author: marianaguimaraens@gmail.com concentrations, temperature, and irradiance), and the interactions between them, on algal growth (Yokoya \& Oliveira 1993, Marinho-Soriano et al. 2002, Bravin \& Yoneshigue-Valentin 2002, Miranda 2010).

The sandstone reefs along the southern coast of Pernambuco State extend seaward, forming marine ridges parallel to the coast that are composed mainly of quartz and bioclasts that become partially exposed during low tides. These reefs serve as attachment substrates for benthic algae, harbor diverse faunas, and are hotspots for biological interactions with the environment (Pereira et al. 2002, Simões et al. 2009). Mansilla \& Pereira (2001) observed significant reductions in red algae biomasses and lower algal diversity during the rainy season on a reef off the southern coast of Pernambuco state that were found to be related to rainfall, temperature, and salinity. Abiotic factors (such as temperature, nutrient concentrations and salinity) together with biological interactions have been shown to control the spatial-temporal distributions of benthic algae (Sauer-Machado et al. 1992, Guimaraens \& Coutinho 1996), which in turn affects macroalgal abundance and hydrodynamic transport (Biber et al. 2004). The Piedade reefs have been impacted by human use, organic pollution, and industrial wastes (Pereira et al. 2002), so that studies on algal populations in this 
environment could aid in establishing policies designed to preserve and manage reef ecosystems.

Nonlinear models that simulate variations in biomass of single species have been developed (Guimaraens et al. $2005,2008)$ wich can describe the trophic structures of reef environments that include algae as primary producers (McClanahan 1995). Models of tropical benthic communities still require greater refinement, however, especially in terms of parameters such as recruitment and interspecific competition (Biber et al. 2004) between algae and invertebrates (Vinueza et al. 2006, Guimaraens et al. 2011a). The model described here considers physiological processes that mimic competitive interactions (Fong et al. 1994, Guimaraens et al. 1996, 2005) and their effects on temporal variations of Gracilaria and Hypnea assemblages through the use of different nutrient absorption curves (Fong et al. 1994, Biber et al. 2004) and different photosynthesis rates for these genera. The present study therefore sought to evaluate the seasonal variations of both environmental factors and Gracilaria and Hypnea assemblages on the reef platforms of Piedade Beach (Pernambuco State) and use ecological modeling to test the hypothesis that model parameters (representing abiotic factors) affect the temporal abundances of these algae to different degrees.

\section{MATERIAL AND METHODS}

\section{Study Area}

Piedade Beach is approximately $9.8 \mathrm{~km}$ long and is located within the Jaboatão dos Guararapes District on the southern coast of Pernambuco State, Brazil $\left(08^{\circ} 11^{\prime} 08^{\prime \prime} \mathrm{S}\right.$ and $34^{\circ} 55^{\prime} 04^{\prime \prime} \mathrm{W}-08^{\circ} 11^{\prime} 03^{\prime \prime} \mathrm{S}$ and $\left.34^{\circ} 55^{\prime} 03^{\prime \prime} \mathrm{W}\right)$. The coastline there is composed of a coastal plain formed by fluvial and marine deposits, and originally included a strip of sand dune vegetation that has now been built over (Pereira et al. 2002). The regional climate is tropical, with an average annual temperature of $26^{\circ} \mathrm{C}$ and a distinct rainfall pattern composed of a dry season (September-February) with rainfall below $100 \mathrm{~mm}$, and a rainy season (March-August) with rainfall above $100 \mathrm{~mm}$ (Cavalcanti \& Kempf 1967-69). Piedade Beach is also impacted by the Jaboatão River that delivers upstream pollution from industrial sites and urban areas (Pereira et al. 2002), and by direct physical damage due to trampling (tourism/leisure).

\section{Field and Laboratory Work}

Algae samples were collected randomly from five $20 \times 20 \mathrm{~cm}$ plots in a reef pool in the midlittoral zone during low tide periods in April, June, August, October, and December/2009 and in January and March/2010. The collected algae were removed to the Phycology Laboratory of the Federal Rural University of Pernambuco where they were sorted and identified. Algal dry weights were obtained by drying each sample (in foil bags) in an oven at $60^{\circ} \mathrm{C}$ for 72 hours, and then weighing them on an analytical balance. Water temperatures and irradiance levels were measured in situ near the sampling plots. Water samples were collected on a monthly basis near the outer edge of the reef (where the ocean water penetrates into the reef platform) to determine the water temperature, $\mathrm{pH}$, and oxygen and salinity levels, as well as the concentrations of ammonia, nitrate, and phosphate. The temperature, salinity, irradiance and nutrients values were incorporated into the biomass simulation model as empirical forcing functions.

Water samples were transferred to $300 \mathrm{~mL}$ plastic bottles and frozen for transport to the Chemistry Laboratory of the Oceanography Department at the Federal University of Pernambuco. The techniques used for determining salinity and nutrient levels were based on the methods described by Strickland \& Parsons (1972) and Grasshoff et al. (1983): $\mathrm{N}$-ammonia nitrogen (hereafter referred to as $\mathrm{N}$-ammonia; $\left.\mathrm{NH}_{3}-\mathrm{NH}_{4}-\mathrm{N}\right)$, N-nitrate $\left(\mathrm{NO}_{3}-\mathrm{N}\right)$, and P-phosphate $\left(\mathrm{PO}_{4}-\mathrm{P}\right)$.

\section{Statistical Analyses}

Principal Component Analyses were performed on the biomass measurements and the salinity, temperature, irradiance, $\mathrm{pH}$, and nutrient values. One-way ANOVAs were used to determine seasonal variations in algal biomass. The algal dry weight data $(\mathrm{x})$ was $\log (\mathrm{x}+1)$ transformed before statistical testing. The Tukey test was used to examine differences between monthly biomass averages $(P<0.05)$. The temporal variations in algal dry weights were used to calibrate the model. Simulation results were compared with the field data for Gracilaria and Hypnea using linear regression analyses. Irradiance measured at the reef pool varied between 27.33 and $169.8 \mu \mathrm{mol}$ photons $\mathrm{m}^{-2} \mathrm{~s}^{-1}$, and this data was also interpolated and included in the model to simulate algal biomass. Algal dispersion coefficient values ranged from 0.348 to 0.002 in the model and were correlated with the rainfall data for Jaboatão dos Guararapes $(r=0.75$, $P<0.05$ ). Rainfall (as measured at the local ITEP/LAMEPE government weather station) was highest in April/2009 $(268.9 \mathrm{~mm})$ and lowest in October/2009 $(6.0 \mathrm{~mm})$. Sensitivity analyses were conducted using initial algal biomass conditions and model parameters.

\section{Biomass Model}

The simulation model for algal populations was developed using the Ithink ${ }^{\mathrm{TM}}$ software package; model parameter values were obtained by manual calibration with the end ranges cited in the literature (table 2 ) and validated by sensitivity analyses. The basic simulation equation for algal biomass ( $B$ in $\mathrm{g} \mathrm{d} \mathrm{wt} \mathrm{m}^{-2}$ ) at each daily time step was (1): 


$$
\frac{d B}{d t}=(\mu-\Omega) B-\alpha
$$

where the $\mu$ and $\Omega$ coefficients represent growth and loss respectively. The two algal populations were simulated separately using two groups of equations that differed with respect to the parameter values used. The forcing data in the model were temperature and salinity, with the time series representing irradiance and nutrient resources utilized by both Gracilaria and Hypnea populations. The alpha $(\alpha)$ coefficient in equation (1) represents algal dispersion (Zoffoli 2009). The dispersion functions were obtained by calibration, and represent the effects of wind and rain; the same dispersion time series was used for both algae

$$
\mu=\mu \max f(T) f(S) f(I) f(N) f(P) f(K)
$$

The parameter $\mu$ max represents the optimal algal growth rate obtained by calibrations based on the range of values cited in the literature. The $f(T)$ function represents the effect of temperature on algal development; the other functions in Equation 2 simulate interactions between salinity, irradiance, nitrogen, and phosphorus parameters, respectively, as well as the carrying capacity function $(f(K))$ (Guimaraens et al. 2005).

Algal loss and senescence, represented by the term $\Omega$, are proportional to algal biomass and the incorporated field temperature values (temp, table 1). The mortality rate is inversely proportional to the growth functions from Equation 2.

$$
\Omega=\frac{\Omega \max 0.1^{(\text {temp }-\theta)} B}{B+K d f(T) f(S) f(I) f(N) f(P) f(K)}
$$

In Equation 3, $K d$ represents the half saturation constant for mortality. The temperature coefficient $\theta$, obtained by calibration, was 32 for Hypnea and 33 for Gracilaria (which may reflect algal acclimation). Equation 4 represents an exponential relationship governed by the difference between field data (temp) and the optimal temperature for the algae (top). The lambda coefficient was obtained through model calibration.

$$
f(T)=\exp ^{-\lambda(t e m p-t o p)^{2}}
$$

The photosynthetic saturation function in the model represents algal photosynthetic efficiency (5), where $I o$ is the daily irradiance based on interpolated field data (table 1). The light extinction coefficients $(\mathrm{C} i)$ were 0.7 for Gracilaria and 0.8 for Hypnea and represent average light extinctions as a function of turbidity, depth, and competition among the algae. In equation (5) $K i$ is the photosynthetic half-saturation constant.

$$
f(I)=\frac{\text { Cilo }}{\text { Cilo }+K i}
$$

Equation (6) represents the limiting effect of salinity on the species studied in relation to optimal salinity (sopt) for algal development. Salinity values measured in the field served as inputs for the model ( $\mathrm{sal}$, table 1). The $\lambda$ s coefficients were obtained through model calibration.

$$
f(S)=\exp ^{-\lambda s(s a l-s o p t)^{2}}
$$

The algal biomass model also considers growth as a function of an internal nutrient quota within the algal thallus (Droop 1983, Guimaraens et al. 2005), with the absorption of nitrogen and phosphorus being represented as a function of their seawater concentrations. Thus, the internal nutrient quotas were also considered state variables in the model.

$$
\begin{aligned}
& \frac{d N}{d t}=N H \text { upt }- \text { NOupt }-\mu N \\
& \frac{d P}{d t}=\text { POupt }-\mu P
\end{aligned}
$$

The variables $N$ and $P$ represent the internal concentrations quotas of nitrogen and phosphorus (mg g ${ }^{-1} \mathrm{~d}$ wt), and Nupt, NOupt, and POupt are the absorption rates for ammonia, nitrate, and phosphate respectively. The equations presented below represent the absorption of ammonia, nitrate, and phosphate, and are functions of their maximum absorption speeds and half saturation constants

Table 1. Hydrological parameters of the study area.

\begin{tabular}{cccccccc}
\hline Data & $\begin{array}{c}\text { Salinity } \\
\% \text { \% }\end{array}$ & $\mathrm{pH}$ & $\begin{array}{c}\mathrm{NH}_{3}-\mathrm{N} \\
\mu \mathrm{mol} \mathrm{L}\end{array}$ & $\begin{array}{c}\mathrm{NO}_{3}-\mathrm{N} \\
\mu \mathrm{mol} \mathrm{L}^{-1}\end{array}$ & $\begin{array}{c}\mathrm{PO}_{4}-\mathrm{P} \\
\mu \mathrm{mol} \mathrm{L}^{-1}\end{array}$ & $\begin{array}{c}\text { Temperature } \\
{ }^{\circ} \mathrm{C}\end{array}$ & $\begin{array}{c}\text { Irradiance } \\
\mu \text { mol photons } \mathrm{m}^{-2}\end{array}$ \\
\hline $4 / 20 / 2009$ & 20.18 & 8.64 & 0.01 & 2.00 & 0.44 & 33.7 & 27.33 \\
$6 / 5 / 2009$ & 15.26 & 8.69 & 0.26 & 3.70 & 0.91 & 28 & 93.71 \\
$7 / 23 / 2009$ & 16.20 & 8.92 & 0.23 & 3.60 & 1.00 & 30.6 & 149.42 \\
$8 / 20 / 2009$ & 20.45 & 8.94 & 0.01 & 2.60 & 0.64 & 28.7 & 20.93 \\
$9 / 20 / 2009$ & 30.53 & 8.27 & 0.01 & 1.30 & 0.12 & 31.5 & 65.66 \\
$10 / 19 / 2009$ & 24.29 & 8.63 & 0.07 & 1.60 & 0.74 & 33.7 & 94.89 \\
$11 / 13 / 2010$ & 28.07 & 8.38 & 0.18 & 0.50 & 0.07 & 30 & 16.20 \\
$12 / 14 / 2010$ & 27.53 & 8.45 & 0.15 & 0.30 & 0.30 & 30.8 & 169.80 \\
$1 / 29 / 2010$ & 26.73 & 8.41 & 0.49 & 2.90 & 0.35 & 32.5 & 145.99 \\
$3 / 2 / 2010$ & 31.54 & 8.64 & 0.31 & 1.10 & 0.23 & 33.9 & 74.33 \\
\hline
\end{tabular}


(table 2), with the time series being based on interpolated field data of nutrient concentrations (NHconc, NOconc, and POconc).

$$
\begin{aligned}
\text { NHupt } & =\frac{\text { VNHmax NHconc }}{\text { KmNH+NHconc }} \\
\text { NOupt } & =\frac{\text { VNOmax NOconc }}{\text { KmNO+NOconc }} \\
\text { POupt } & =\frac{\text { VPOmax POconc }}{\text { KmPO + POconc }}
\end{aligned}
$$

The nutrient limitation functions $f(N)$ and $f(P)$ assume that algal growth decreases as internal nutrient concentrations approach minimum nitrogen and phosphorus values (table 2).

$$
\begin{aligned}
& f(N)=1-\frac{Q N \min }{N} \\
& f(P)=1-\frac{Q P \min }{P}
\end{aligned}
$$

The model also assumes that Gracilaria and Hypnea growth is limited by intraspecific competition based on carrying capacity $(K)$ values that reflect biomass values observed in the field during the growing season (Guimaraens et al. 2005, 2008, table 2).

$$
f(K)=1-\frac{B}{K}
$$

Sensitivity analyses for model outputs were performed using equation (15), varying the initial biomass conditions and each parameter by $\pm 10 \%$ to calculate percentage changes in relation to baseline runs (Guimaraens et al. 2008, 2011a).

$$
\text { Percent Change }=\frac{(100)}{N \text { Savg }}(\Sigma(|\mathrm{S} 1-\mathrm{S} 2|))
$$

Where $N$ is the total simulation in days, Savg the average biomass value for the baseline run for each algal genus, $S 1$

\begin{tabular}{|c|c|c|c|c|c|c|}
\hline Symbol & Description & Units & $\begin{array}{l}\text { Values for } \\
\text { Gracilaria }\end{array}$ & Sources & $\begin{array}{l}\text { Values for } \\
\text { Hypnea }\end{array}$ & Sources \\
\hline$I C$ & Model initial condition & $\mathrm{gdwt} \mathrm{m}^{-2}$ & 100 & field & 46 & field \\
\hline$K$ & Carrying capacity & $\mathrm{gdwt} \mathrm{m}^{-2}$ & 500 & field & 200 & field \\
\hline$K d$ & $\begin{array}{l}\text { Half-saturation constant for } \\
\text { mortality }\end{array}$ & $\mathrm{gdwt} \mathrm{m}^{-2}$ & 50 & Calibration & 20 & Calibration \\
\hline$\mu \max$ & Maximum growth rate & Day $^{-1}$ & 0.8 & Biber et al. 2004 & 0.6 & $\begin{array}{l}\text { Rosenberg et al. } \\
1995\end{array}$ \\
\hline$\Omega \max$ & Maximum death rate & Day $^{-1}$ & 0.00015 & Calibration & 0.0001 & Calibration \\
\hline Тор & Optimun temperature & ${ }^{\circ} \mathrm{C}$ & 30 & Miranda 2010 & 25 & Biber et al. 2004 \\
\hline$K i$ & $\begin{array}{l}\text { Half-saturation constant for } \\
\text { photosyntesis }\end{array}$ & $\mu \mathrm{mol}$ photons $\mathrm{m}^{-2}$ & 40 & Miranda 2010 & 30 & $\begin{array}{l}\text { Yokoya et al. } \\
2007\end{array}$ \\
\hline Sopt & Optimun salinity & Adimensional & 37 & Biber et al. 2004 & 39 & Biber et al. 2004 \\
\hline VNHmax & $\begin{array}{l}\text { Maximum uptake rate for } \\
\text { ammonium }\end{array}$ & $m g \mathrm{~L}^{-1}$ & 35 & Carneiro 2007 & 55 & Calibration \\
\hline VNOmax & $\begin{array}{l}\text { Maximum uptake rate for } \\
\text { nitrate }\end{array}$ & $\mathrm{mg} \mathrm{L}^{-1}$ & 40 & Carneiro 2007 & 30 & Hanisak 1983 \\
\hline VPOmax & $\begin{array}{l}\text { Maximum uptake rate for } \\
\text { phosphate }\end{array}$ & $\mathrm{mg} \mathrm{L}^{-1}$ & 10 & Carneiro 2007 & 20 & Calibration \\
\hline$K M N H$ & $\begin{array}{l}\text { Half-saturation constant for } \\
\text { ammonium }\end{array}$ & $m g \mathrm{~L}^{-1}$ & 3 & Biber et al. 2004 & 16.6 & Hanisak 1983 \\
\hline$K M N O$ & $\begin{array}{l}\text { Half-saturation constant for } \\
\text { nitrate }\end{array}$ & $\operatorname{mg~L} \mathrm{L}^{-1}$ & 3 & Biber et al. 2004 & 5 & Hanisak 1983 \\
\hline KMPO & $\begin{array}{l}\text { Half-saturation constant for } \\
\text { phosphate }\end{array}$ & $\operatorname{mg~L} L^{-1}$ & 1 & Biber et al. 2004 & 4.9 & Calibration \\
\hline QNmin & Minimum quota for nitrogen & $m g g d t^{-1}$ & 5 & Calibration & 5 & Calibration \\
\hline QPmin & $\begin{array}{l}\text { Minimum quota for } \\
\text { phosphorus }\end{array}$ & $\mathrm{mg} \mathrm{g} \mathrm{d} \mathrm{wt}^{-1}$ & 1 & Calibration & 0.5 & Calibration \\
\hline
\end{tabular}
the baseline biomass value, and $S 2$ the biomass value for each sensitivity run.

\section{RESULTS}

The first two components of the PCA explained $67.44 \%$ of the data variance and indicated that Gracilaria

Table 2. Model parameters for algal biomass simulations. 
biomass was positively correlated with temperature and salinity. Additionally, algal biomass was negatively correlated with irradiance and $\mathrm{pH}$, as Gracilaria is not characteristic of estuarine environments and can be limited by low irradiance levels (table 1, figure 1). Hypnea biomass was negatively correlated with irradiance levels and with ammonia concentrations in the reef pool samples (figure 1). Gracilaria caudata and Hypnea musciformis were the most abundant components of the algal community in the study area, and their opposing abundance patterns in our samples suggest that competition is an important structuring factor in these populations.

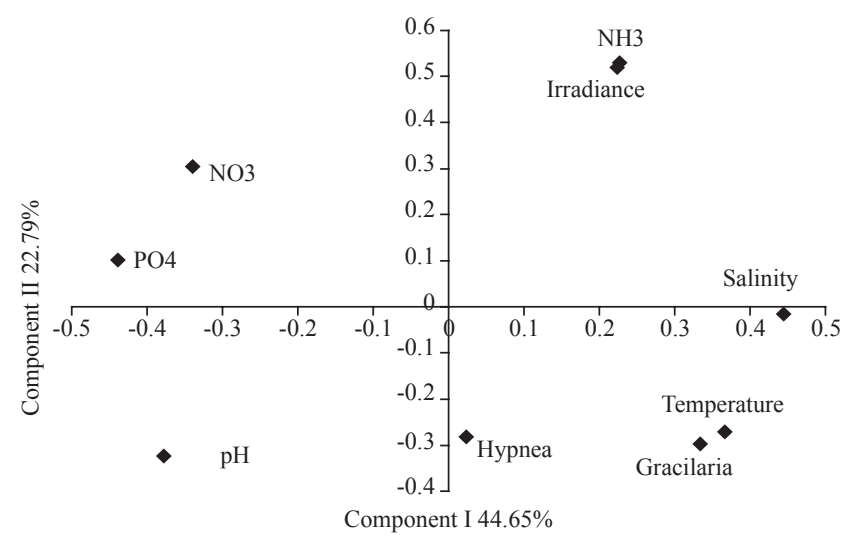

Figure 1. Principal Component Analysis of the environmental data collected at the Reef Pool.

Salinity values at the sampling site were lower during the rainy season (between 20.45 and 15.26 units ), indicating a strong influence of the estuarine environment (table 1). Water temperatures at the sampling site ranged between $28{ }^{\circ} \mathrm{C}$ and $33.9{ }^{\circ} \mathrm{C}$, but it did not show any clear seasonal pattern. Dissolved oxygen values ranged from 9.2 to $18.1 \mathrm{mg} \mathrm{L}^{-1}$, characteristic of sites having intense photosynthetic activities. Nitrate showed the highest concentration of all of the nutrients in water samples, ranging between 3.7 and $2 \mu \mathrm{mol} \mathrm{L}^{-1}$ during the rainy season; the highest phosphate values were measured in June and July/2009 (0.91 and $1 \mu \mathrm{mol} \mathrm{L}^{-1}$ respectively). In the present study, using calibration experiments, an optimal water temperature of approximately $30^{\circ} \mathrm{C}$ was observed for Gracilaria, which presumably reflects the acclimation of this alga to this tropical intertidal habitat. The optimal water temperature for Hypnea growth in the model was $25^{\circ} \mathrm{C}$ (table 2).

The average biomass of Gracilaria in August/2009 was different from those of April/2009 and March/2010 $(P<0.05)$, and its dry weight peaked at approximately $120 \mathrm{~g} \mathrm{~d} \mathrm{wt} \mathrm{m}^{-2}$ in the reef pool (figure 2, table 3 ). The average biomass of Hypnea, on the other hand, was always below $50 \mathrm{~g} \mathrm{~d} \mathrm{wt} \mathrm{m}^{-2}$ and did not vary significantly during the study period (table 4). The fit between the simulated algal biomass values and the field data using linear regression was statistically significant $(\mathrm{r}=0.79$, $P<0.01$ ), suggesting that the abiotic parameters included in the model, in addition to competition, serve to regulate
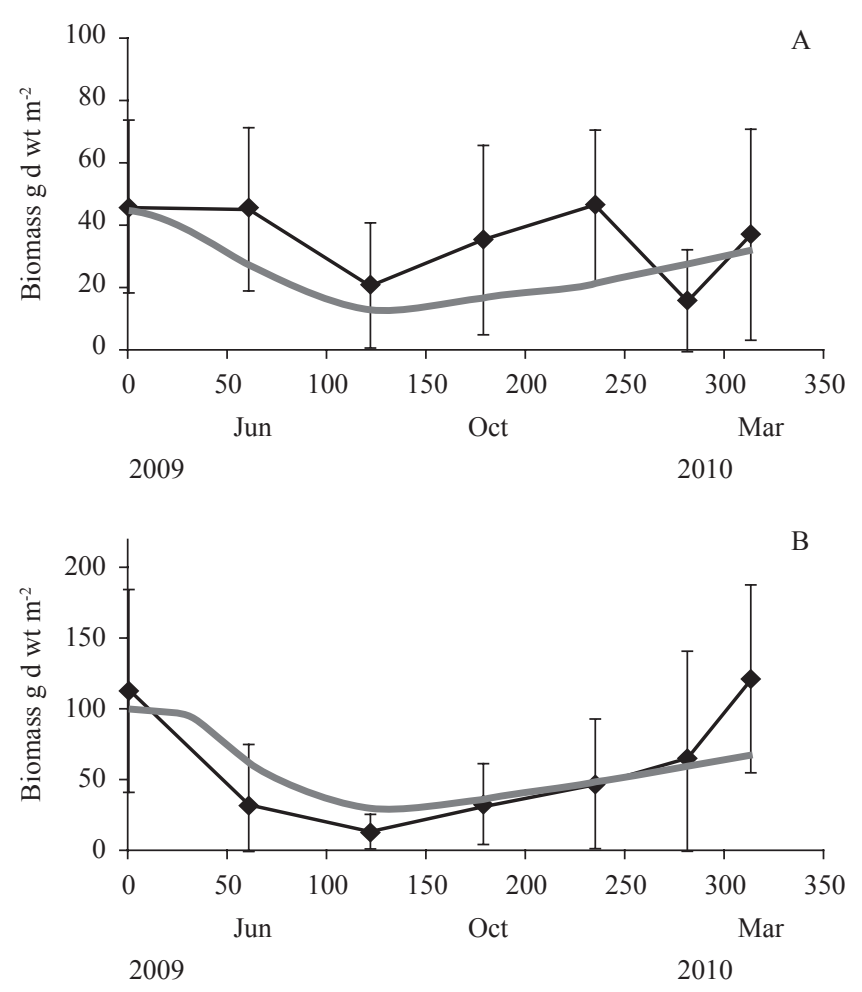

Figure 2. Algal simulations and average biomasses of Hypnea (A) and Gracilaria (B) ( \pm standard deviations) collected at the Reef Pool.

Table 3. One-Way ANOVA of Gracilaria biomass.

\begin{tabular}{lcccccc}
\hline Source of variation & Degrees of freedom & SS & MS & F & $P$-level & F crit \\
\hline Between Groups & 6 & 1.4026 & 0.2338 & 3.2873 & 0.0147 & 2.4591 \\
Within Groups & 27 & 1.9201 & 0.0711 & & & \\
Total & 33 & 3.3227 & & & & \\
\hline
\end{tabular}


Table 4. One-Way ANOVA of Hypnea biomass.

\begin{tabular}{lcccccc}
\hline Source of variation & Degrees of freedom & SS & MS & F & $P$-level & F crit \\
\hline Between Groups & 6 & 0.2117 & 0.0353 & 0.6216 & 0.7113 & 2.4741 \\
Within Groups & 26 & 1.4754 & 0.0567 & & & \\
Total & 32 & 1.6871 & & & & \\
\hline
\end{tabular}

populations of these algae. The model was sensitive to initial biomass conditions, however, which had values that varied between 15 and 20\% from the baseline runs for both algae. Sensitivity analyses of model parameters yielded values that generally varied less than $10 \%$ from the baseline and sensitivity run biomass values (table 5). Model simulations for both algae showed biomass variations greater than $10 \%$ in terms of the optimum salinity parameters (table 5), confirming the importance of the dispersion functions affecting temporal variations in Gracilaria and Hypnea biomasses.

Table 5. Sensitivity analyses of Gracilaria and Hypnea to initial conditions and model parameters.

\begin{tabular}{lccccc}
\hline & $\begin{array}{c}\text { Gracilaria model } \\
\text { parameters }\end{array}$ & & \multicolumn{2}{c}{$\begin{array}{c}\text { Hypnea model } \\
\text { parameters }\end{array}$} \\
\cline { 2 - 3 } \cline { 5 - 6 } & $+10 \%$ & $-10 \%$ & & $+10 \%$ & $-10 \%$ \\
\hline IC & $\mathbf{1 7 . 1 9}$ & $\mathbf{1 6 . 8 0}$ & & $\mathbf{1 8 . 1 3}$ & $\mathbf{1 8 . 0 8}$ \\
$K$ & 0.49 & 0.59 & & 0.68 & 0.83 \\
Kd & 0.47 & 0.48 & & 0.06 & 0.06 \\
$\mu$ max & 3.71 & 3.80 & & 5.06 & 5.19 \\
Smax & 6.32 & 6.45 & & 1.00 & 1.00 \\
Top & 0.48 & 2.87 & & 9.56 & 12.21 \\
Ki & 1.55 & 1.67 & & 1.50 & 1.59 \\
Sopt & $\mathbf{1 7 . 0 1}$ & $\mathbf{1 8 . 7 2}$ & & $\mathbf{2 1 . 2 6}$ & $\mathbf{2 4 . 2 6}$ \\
VNHmax & 0.03 & 0.03 & & 0.02 & 0.02 \\
VNOmax & 0.22 & 0.26 & & 0.31 & 0.37 \\
VPOmax & 0.22 & 0.26 & & 0.15 & 0.18 \\
KMNH & 0.02 & 0.03 & & 0.02 & 0.02 \\
KMNO & 0.15 & 0.15 & & 0.25 & 0.25 \\
KMPO & 0.16 & 0.16 & & 0.15 & 0.15 \\
QNmin & 0.26 & 0.28 & & 0.38 & 0.39 \\
QPmin & 0.24 & 0.25 & & 0.18 & 0.18 \\
\hline & & & & & \\
\hline
\end{tabular}

\section{DISCUSSION}

In their study of algal communities at Itamaracá, PE Silva et al. (1987) reported lower Gracilaria biomass values during the rainy season than during the dry summer season that could be related to water turbidity, rainfall, and wind dispersion. Principal Component Analyses showed negative correlations between algal biomasses and nutrients, as reef community eutrophication is greater during the rainy season. Bezerra \& MarinhoSoriano (2010), however, reported a positive correlation between $\mathrm{NH}_{4}^{+}$and Gracilaria birdiae Plastino \& EC Oliveira biomass during the dry season, while MarinhoSoriano et al. (2001) observed higher biomass and agar production by Gracilaria cervicornis (Turner) J. Agardh during the dry season in northeastern Brazil, with peak biomass values near $400 \mathrm{~g} \mathrm{~m}^{-2}$ during the summer/dry season. Both the growth rate and carrying capacity $(\mathrm{K})$ of Gracilaria were higher than those of Hypnea in the simulation model despite the presence of epiphytes such as Hypnea growing on Gracilaria. These interactions may affect the carrying capacities of dominant algae populations in reef and rocky-shore communities (Guimaraens et al. 1996).

Developmental experiments testing Gracilaria caudata growth in the laboratory have indicated that this species is euryhaline and has an optimal salinity of 35 ppt in Brazil (Miranda 2010), although Carneiro (2007) reported that low salinity can limit the growth of G. cervicornis. Optimal temperatures for laboratory cultivation of Gracilaria specimens from the Brazilian coastranged from $25^{\circ} \mathrm{C}$ to $30^{\circ} \mathrm{C}$ (Yokoya \& Oliveira 1993, Miranda 2010), while measurements of the photosynthetic output of Gracilaria cornea J. Agardh in the Florida Keys identified an optimal temperature range between $25^{\circ} \mathrm{C}$ and $35^{\circ} \mathrm{C}$ (Dawes et al. 1999). Coastal productivity at Piedade Beach may also be limited by the presence of suspended solids during the rainy season (Passavante \& Feitosa 1995), so that more frequent measurements of abiotic parameters and in situ irradiance levels in the water column (Brush \& Nixon 2010) could improve model forecasting in that region. Model forecasting could also be improved by laboratory cultivation experiments that evaluated the sensitivities of local species to a wide spectrum of environmental factors (including salinity and temperature) and determine their nutrient uptake curves and light requirements. Biomass simulation experiments that did not include dispersion coefficients (alpha) did not generate seasonal patterns for the algae and could only qualitatively represent competition. 
Hypnea biomass was sensitive to a $10 \%$ decrease in its optimum temperature in the models. Experimental calibrations of the biomass model indicated an optimal temperature of $25^{\circ} \mathrm{C}$ for Hypnea, confirming the findings of Bravin and Yoneshigue-Valentin (2002) for optimal growth under nutrient-enriched conditions. The maximum absorption rates of ammonia and phosphate related to Hypnea biomass accumulation in the model suggest that this alga absorbs nutrients more efficiently at higher concentrations than does Gracilaria (which is known to absorb nutrients more effectively than Hypnea) (Chow et al. 2007). Gracilaria has also been described as an alga adapted to low irradiance levels (Dawes et al. 1999, Miranda 2010), as it was encountered under conditions of partial submersion on the Piedade Reef platform, particularly during the rainy season.

Hypnea also has a competitive advantage over Gracilaria in relation to environmental light availability - due to its lower half-saturation photosynthetic coefficient (Ki) (Biber et al. 2004). This at least partially explains the greater abundance of Hypnea in the reef pool as compared to other more exposed regions of the intertidal zone. It should also be noted that benthic algal community structures can be maintained by the occurrence of species with different ecological characteristics during the different seasons of the year and this occupation of different reef micro-habitats, as blooms of ephemeral Chlorophyta have been observed during the rainy season at Piedade Reef (Guimaraens et al. 2011b). In spite of relatively recent environmental impacts such as pollution and trampling, rapid recycling of chemical and biological resources was observed as indicated by high levels of dissolved oxygen, an alkaline $\mathrm{pH}$ throughout the study area, and the significant recovery of Gracilaria biomass after the rainy season.

Acknowledgements - This research was partially funded by $\mathrm{CNPq}$ (Brazilian National Research Council) through Edital Universal 2007 grant number 470424/2007-9.

\section{REFERENCES}

Bezerra AF, Marinho-Soriano E. 2010. Cultivation of the red seaweed Gracilaria birdiae (Gracilariales, Rhodophyta) in tropical waters of northeast Brazil. Biomass \& Bioenergy 34:1813-1817.

Biber PD, Harwell MA, Cropper Jr WP. 2004. Modeling the dynamics of three functional groups of macroalgae in tropical seagrass habitats. Ecological Modelling 175: 25-54.

Bravin IC, Yoneshigue-Valentin Y. 2002. Influence of environmental factors on the in vitro growth of Hypnea musciformis (Wulfen) Lamouroux (Rhodophyta). Revista Brasileira de Botânica 25:469-474.
Brush MJ, Nixon SW. 2010. Modeling the role of macroalgae in a shallow sub-estuary of Narragansett Bay, RI (USA). Ecological Modelling 221:1065-1079.

Carneiro MAA. 2007. Estudo do crescimento, eficiência de biofiltração e cinética de absorção de nutrientes $\left(\mathrm{N}-\mathrm{NH}_{4}^{+}, \mathrm{N}^{-} \mathrm{NO}_{3}{ }^{-}\right.$e $\left.\mathrm{P}-\mathrm{PO}_{4}{ }^{3-}\right)$ da macroalga Gracilaria cervicornis (Turner) J. Agardh. Dissertação de mestrado, Universidade Federal do Rio Grande do Norte, Natal.

Cavalcanti LB, Kempf M. 1967-69. Estudo da plataforma continental na área do Recife (Brasil). II. Meteorologia e hidrologia. Trabalhos Oceanográficos 9:149-158.

Chow F, Capociama FV, Faria R, Oliveira M. 2007. Characterization of nitrate reductase activity in vitro in Gracilaria caudata J. Agardh (Rhodophyta, Gracilariales). Revista Brasileira de Botânica 30: 123-129.

Dawes CJ, Ordunâ-Rojas J, Robledo D. 1999. Response of the tropical red seaweed Gracilaria cornea to temperature, salinity and irradiance. Journal of Applied Phycology 10:419-425.

Droop MR. 1983. 25 years of algal growth kinetics: a personal view. Botanica Marina 26:99-112.

Fong P, Foin TC, Zedler JB. 1994. A simulation model of lagoon algae based on nitrogen competition and internal storage. Ecological Monographs 64:225-247.

Guimaraens MA, Coutinho R. 1996. Spatial and temporal variation of benthic marine algae at the Cabo Frio upwelling region, Rio de Janeiro, Brazil. Aquatic Botany 52:283-299.

Guimaraens MA, Coimbra CA, Coutinho R. 1996. Modeling competition between Laurencia obtusa (Ceramiales, Rhodophyta) and Hypnea spinella (Gigartinales, Rhodophyta) at Cabo Frio Island, Rio de Janeiro, Brazil. Hydrobiologia 327:273-276.

Guimaraens MA, Paiva AM, Coutinho R. 2005. Modeling Ulva spp. dynamics in a tropical upwelling region. Ecological Modelling 188:448-460.

Guimaraens MA, Gonçalves JEA, Lourenço SO, Coutinho R. 2008. Sensitivity analyses of population dynamics for Ulva spp. and Sargassum furcatum at the Cabo Frio upwelling region of Brazil. Journal of Biological Systems 16:579-596.

Guimaraens MA, Luz BRA, Silva JF, Carneiro JPS. 2011a. Modeling the succession of barnacles and mussels on a sandstone reef in Pernambuco State, Brazil. Hydrobiologia 658:365-372.

Guimaraens MA, Silva JAM, Falcão D. 2011b. Temporal variability in macroalgae recruitment and succession on sandstone reefs at Piedade Beach - PE, Brazil. Neotropical Biology and Conservation 6:170-177.

Grasshoff KM, Ehrhadt K, Kremilin, K. 1983. Methods of seawater analysis. Verlag Chemie, Deerfield Beach.

Hanisak MD. 1983. The nitrogen relationships of marine macroalgae. In Nitrogen in the marine environment (EJ Carpenter, DG Capone, eds.). Academic Press, New York, p.699-730. 
Marinho-Soriano E, Silva TSF, Moreira WSC. 2001. Seasonal variation in the biomass and agar yields from Gracilaria cervicornis and Hydropuntia cornea from Brazil. Bioresource Technology 77:115-201.

Marinho-Soriano E, Morales C, Moreira WSC. 2002. Cultivation of Gracilaria (Rhodophyta) in shrimp pond effluents in Brazil. Aquaculture Research 33:1081-1086.

Mansilla A, Pereira SMB. 2001. Comunidades y diversidad de macroalgas en pozas intermareales de arrecifes. In Sustentabilidad de la biodiversidad (K Alveal, T Antezana, eds.). Universidad de Concepción-Chile, p.315-330.

McClanahan TR. 1995. A coral reef ecosystem-fisheries model: impacts of fishing intensity and catch selection on reef structure and processes. Ecological Modelling $80: 1-19$

Miranda GEC. 2010. Monitoramento, manejo e restauração de populações de Gracilaria caudata (Rhodophyta, Gigartinales) degradadas pela explotação comercial. Tese de doutorado, Universidade Federal de Pernambuco, Recife.

Oliveira Filho EC. 1998. The seaweed resources of Brazil. In Seaweed resources of the world (AT Critcheley, M Ohno, eds.). Japan International Cooperation Agency, Yokosuka, p.366-371.

Passavante JZO, Feitosa FAN. 1995. Produção primária do fitoplâncton da plataforma continental de Pernambuco (Brasil): Área de Piedade. Boletim Técnico Científico CEPENE 3:7-22.

Pereira SMB, Oliveira-Carvalho MF, Angeiras JAP, BandeiraPedrosa ME, Oliveira, NMB, Torres J, Gestinari LMS, Cocentino ALM, Santos MD, Nascimento PRF, Cavalcanti RR. 2002. Benthic marine algae of the State of Pernambuco. In Diagnosis of the biodiversity of Pernambuco (M Tabarelli, JMC Silva, eds.). Massangana, Recife, p.97-124.
Rosenberg G, Littler DS, Littler MM, Oliveira EC. 1995. Primary production and photosynthetic quotients of seaweeds from São Paulo State, Brazil. Botanica Marina 38:369-377.

Sauer-Machado KRS, Chapman ARO, Coutinho R. 1992. Patch structure in a tropical rocky shore community in Brazil: a mosaic of successional states? Ophelia 35:187195.

Silva RL, Pereira SMB, Oliveira EC, Eston VR. 1987. Structure of a bed of Gracilaria spp. (Rhodophyta) in northeastern Brazil. Botanica Marina 30:517-523.

Simões IP, Guimaraens MA, Oliveira-Carvalho MF, Valdevino J, Pereira SMB. 2009. Avaliação florística e sucessão ecológica das macroalgas em recifes na praia de Piedade - PE. Neotropical Biology and Conservation 4:49-56.

Strickland JDH, Parsons TR. 1972. A practical handbook of seawater analysis. Bulletin 167, Fisheries Research Board of Canada, Ottawa.

Vinueza LR, Branch GM, Branch ML, Bustamante RH. 2006. Top-down herbivory and bottom-up El Niño effects on Galápagos rocky-shore communities. Ecological Monographs 76:111-131.

Yokoya NS, Oliveira EC. 1993. Effects of temperature and salinity on spore germination and sporeling development in South American agarophytes (Rhodophyta). Japanese Journal of Phycology 41:283-293.

Yokoya NS, Necchi O, Martins AP, Gonzalez, SF, Plastino EM. 2007. Growth responses and photosynthetic characteristics of wild and phycoerythrin-deficient strains of Hypnea musciformis (Rhodophyta). Journal of Applied Phycology 19:197-205.

Zoffoli L. 2009. Estudo da variabilidade temporal da abundância fitoplanctônica na região de ressurgência do Cabo Frio, RJ, através de diferentes abordagens e escalas de análises. Dissertação de mestrado, Universidade Federal Fluminense, Niterói. 